\title{
Enumeration of Listeria monocytogenes at Low Contamination Levels in Several Food Matrices Using a Membrane Filtration Method
}

Nicolas Baudouin • Bertrand Lombard • Nelly Audinet • Nathalie Gnanou Besse

Published online: 22 May 2009

(C) Springer Science + Business Media, LLC 2009

Erratum to: Food Anal. Methods

DOI 10.1007/s12161-009-9072-5

In the original version of this article, at the Reference section, journal title listed for the reference Gnanou Besse et al. 2004 was written incorrectly as "Food Microbiol" for Food Microbiology. It should read "International Journal of Food Microbiology". The exact reference is given below:

Gnanou Besse N, Audinet N, Beaufort A, Colin P, Cornu M, Lombard B (2004) A contribution to the improvement of Listeria monocytogenes enumeration in cold-smoked salmon. Int J Food Microbiol 91, $119-127$

The online version of the original article can be found at http://dx.doi. org/10.1007/s12161-009-9072-5.

N. Baudouin $\cdot$ B. Lombard $\cdot$ N. Audinet $\cdot$ N. Gnanou Besse $(\bowtie)$ Laboratoire d'Etudes et de Recherches sur la Qualité des Aliments et sur les Procédés agro-alimentaires,

Agence française de sécurité sanitaire des aliments,

Afssa, 23 avenue du Général de Gaulle,

94706 Maisons Alfort Cedex, France

e-mail: n.besse@afssa.fr 